\title{
The Role of Business Center Using Sentiment Analysis to Foster Entrepreneurial Spirit in Vocational High School
}

\author{
Yogi Nurfauzi $^{1, *}$, Suyanto $^{2}$, Sukidjo $^{2}$, Munsyi $^{3}$, Erif Ahdhianto ${ }^{4}$ \\ ${ }^{1}$ Doctoral Program Student, Faculty of Educational Science, Yogyakarta State University, Indonesia \\ ${ }^{1}$ Faculty of High School Teacher Training and Education, STKIP Majenang, Indonesia \\ ${ }^{2}$ Faculty of Graduate School, Yogyakarta State University, Indonesia \\ ${ }^{3}$ Faculty of Da'wah and Communication, UIN Antasari, Indonesia \\ ${ }^{4}$ Department of Elementary School Teacher Education, Universitas Nusantara PGRI Kediri, Indonesia
}

Received June 18, 2020; Revised August 17, 2020; Accepted August 28, 2020

\section{Cite This Paper in the following Citation Styles}

(a): [1] Yogi Nurfauzi, Suyanto, Sukidjo, Munsyi, Erif Ahdhianto, "The Role of Business Center Using Sentiment Analysis to Foster Entrepreneurial Spirit in Vocational High School," Universal Journal of Educational Research, Vol. 8, No. 11, pp. 5151-5157, 2020. DOI: 10.13189/ujer.2020.081114.

(b): Yogi Nurfauzi, Suyanto, Sukidjo, Munsyi, Erif Ahdhianto (2020). The Role of Business Center Using Sentiment Analysis to Foster Entrepreneurial Spirit in Vocational High School. Universal Journal of Educational Research, 8(8), 5151-5157. DOI: 10.13189/ujer.2020.081114.

Copyright $\bigcirc 2020$ by authors, all rights reserved. Authors agree that this article remains permanently open access under the terms of the Creative Commons Attribution License 4.0 International License

\begin{abstract}
VHS graduates must have work-ready qualifications and entrepreneurial spirit to be able to build their own businesses. The purpose of this study is to identify the role of the implementation of BC using SA (BCSA) to foster the entrepreneurial spirit of students in VHS. The research method used is quantitative design with one shoot case study type research with inferential statistics and descriptive statistics used as data analysis techniques. There were 114 study participants, consisting of 96 students, six administrators, and 12 teachers. The researcher found that the implementation of BCSA had a role in fostering the entrepreneurial spirit of VHS students. This foster occurred consistently in aspects of self-confidence, work orientation, and future orientation. Another finding is that the implementation of BCSA provides a positive and significant role in fostering the entrepreneurial spirit. This role has the most beneficial benefits in a row by students, teachers, and administrators. The researcher recommends that BCSA be applied at the VHS level so that students have an entrepreneurial spirit early to prepare graduates or workforce who are better prepared for independent entrepreneurship in the future.
\end{abstract}

Keywords Business Center, Sentiment Analysis, Marketplace, Vocational Education

\section{Introduction}

Vocational high school (VHS) is an education unit that is organized in the formal education pathway for secondary education, and is in a vocational group. VHS has a dual vocational education system that is an education system that is oriented to work skills and entrepreneurial skills in the business world or the world of industry by adjusting the characteristics of competencies of interest [1],[2]. Therefore, students who should have graduated at the VHS level have readiness as workers. In addition, students have readiness to become entrepreneurs independently.

The problems faced at the level of VHS graduates are currently competence under business or industry standards and lack of qualified entrepreneurial skills. Education at the VHS level has not been able to apply entrepreneurship education programs and experiences to students so that VHS graduates have not been able to do the work and have certain entrepreneurship skills [1]. On the other hand, Based on data from the National Statistics Agency, the number of unemployed VHS graduates amounted to 1.383 .022 people or $19.74 \%$ of the total open unemployment [3].

Problems that occur at the VHS level are triggered by the inability of the institution to provide an effective forum for growing entrepreneurial spirit in students [4]. 
Entrepreneurial spirit refers to a person's desire to build, develop, and institutionalize new businesses or entrepreneurs independently [5], [6]. Thus VHS must be better equipped to facilitate the growth of entrepreneurial spirit through entrepreneurship experience in vocational education.

Entrepreneurial experience can be obtained through the utilization of Business Center (BC) in schools. Through a $\mathrm{BC}$, students can learn various experiences in running a business, serving customers, business marketing [7]. To achieve this goal, learning management and the active involvement of stakeholders in the VHS environment are needed. Moreover, today's digital transformation of technology can be utilized to assist stakeholders in providing students with learning experiences in entrepreneurship [8], [9]. One form of digital transformation in the field of entrepreneurship is the marketplace, which is the first choice of people who want to shop digitally [10]. Meanwhile, entrepreneurship is preceded by determining the elements of a product that are being discussed before starting the opinion mining process.

Thus, the utilization of a $\mathrm{BC}$ in a marketplace database will not be optimal if there is no dissertation on how to analyze products that are of public interest. Sentiment Analysis (SA) can be used to sort out product needs and where the source of the product is of interest [11]-[13]. Therefore, the entrepreneurial experience of VHS students can be realized by utilizing the role of $\mathrm{BC}$ as a forum for entrepreneurial activities and SA as a way to analyze products contained in the marketplace database. In this study, the effort to apply BC by using SA is called BCSA. This effort was carried out aimed at fostering the entrepreneurial spirit of VHS students. Hence, the purpose of this study is to identify the role of the implementation of BCSA on fostering entrepreneurial spirit of students at the VHS level.

\section{Literature Review}

\subsection{Business Center in VHS}

In VHS business and management groups, there is an organization called the Business [1]. The BC at VHS is a process of business activity carried out by schools on an ongoing, academic basis with businesses to empower school and environmental residents. This organization is managed professionally in vocational education [14],[15]. In terms of benefits, the $\mathrm{BC}$ is a training and education center for VHS students that serves as a means of school production units and as an entrepreneurial laboratory. Thus, VHS students have the opportunity to carry out sales, calculation or bookkeeping practices [16].

Therefore, the BC at VHS can be seen as a facility for entrepreneurial practice and training in schools. In this study, the $\mathrm{BC}$ is integrated with learning on management and business subjects. This is intended so that students not only receive entrepreneurial knowledge, but also implement it through entrepreneurial activities directly. Learning activities undertaken by students include sales practices, calculations or bookkeeping.

\subsection{Sentiment Analysis}

Sentiment Analysis (SA) is a computational study of attitudes, emotions, opinions, judgments, views of a set of texts whose focus is on extracting, identifying or discovering sentiment characteristics in text units using natural language processing methods, statistics or machine learning. Analysis of the characteristics of sentiments includes the process of classifying textual documents into several classes, such as positive and negative sentiments and the magnitude of the influence and benefits of a product. [11].

SA can be used in a variety of possible domains ranging from consumer products, health services, financial services, social and political events in elections. The trend of research on SA focuses on opinions that state or imply positive or negative sentiment [17]. SA is also useful in the business world such as an analysis of a product that can be done quickly, and is used as a tool to see consumer responses to these products so that users can make strategic steps in the next stages. [18]. SA tools can be used to extract useful information from data obtained from the web or the internet [11],[19].

In this study, SA is carried out by students during learning activities at the BC. SA is conducted by students as a way to calculate people's buying interest from sales products originating from the marketplace database. The integration of SA in learning activities at the $\mathrm{BC}$ is expected to be a solution to foster Entrepreneurial spirit.

\subsection{Entrepreneurial Spirit}

Entrepreneurship is a behavior centered on economic opportunities and resources. Entrepreneurship adopts financial, moral, and social responsibilities to build new and profitable business ideas that can contribute to solving problems that occur during entrepreneurship [14], [20], [21]. Meanwhile, entrepreneurial spirit refers to a personal trait or something of one's own strength for individuals in doing business [22]. Entrepreneurial spirit contributes in shaping attitudes and shaping a person behavior in conducting economic activities [23]. Building an entrepreneurial spirit on young people has an important role in reducing poverty, providing employment opportunities, managing risks, and crime that stems from unemployment [16].

Entrepreneurial spirit of a person is known from its characteristics in terms of self-confidence, originality, work-orientation, risk-taking, leadership, and future-orientation [4],[24]. Self-confidence is the nature of 
someone who refers to beliefs, independence, individuality, and optimism. Originality is the nature of a person that refers to the innovative and creative nature, the ability to overcome new problems, initiative, and the ability to do many things well and knowledge. Work-orientation is the nature of a person that refers to the need for achievement, orientation, profit, perseverance, fortitude, determination and hard work, have a strong drive, energetic, and initiative. Risk-taking is the nature of someone who prefers to take risks and likes to challenge. Leadership is the nature of someone who refers to the behavior as a leader, can get along well, and accept suggestions and criticism. Future-orientation is the nature of someone who refers to foresight, sharpness of perception, and dare to take risks. In this study, the characteristics of entrepreneurial spirit are used as indicators to measure the value of the entrepreneurial spirit of VHS students during and after BCSA implementation.

\section{Methods}

\subsection{Research Design}

This study used a quantitative design with the one shoot case study type, in which numerical data were analyzed to identify the role of BCSA on entrepreneurial spirit. One shoot case study provides certain treatment to research participants and allows evaluation of results during and after treatment [25]. In this study, the role of BCSA was identified for six weeks in the marketplace database, with details of two weeks on Instagram, Shopee, and Tokopedia respectively.

During their stay at the $\mathrm{BC}$, students worked on assignments to analyze products that might gain high public interest in the marketplace database using sentimental analysis. The data obtained were used for consideration in the BCSA for the provision of goods, ideas to conduct marketing strategies, and product development for the future. The flow of SA is shown in Figure 1.

Figure 1 shows the SA process, where when the system is run. In other words, the user can input data from what products are selling well in the market. SA provides information on the data requested by providing output in the form of information based on data that get a lot of positive comments on the product input by the user. This method can be used in BC management to carry out marketing strategies in providing products that are in great demand. This avoids risk when students start opening an entrepreneur. With the data obtained, BC students found in VHS obtain from input materials and studies to prepare students how to deal with preparations before building an entrepreneur to face business competition.

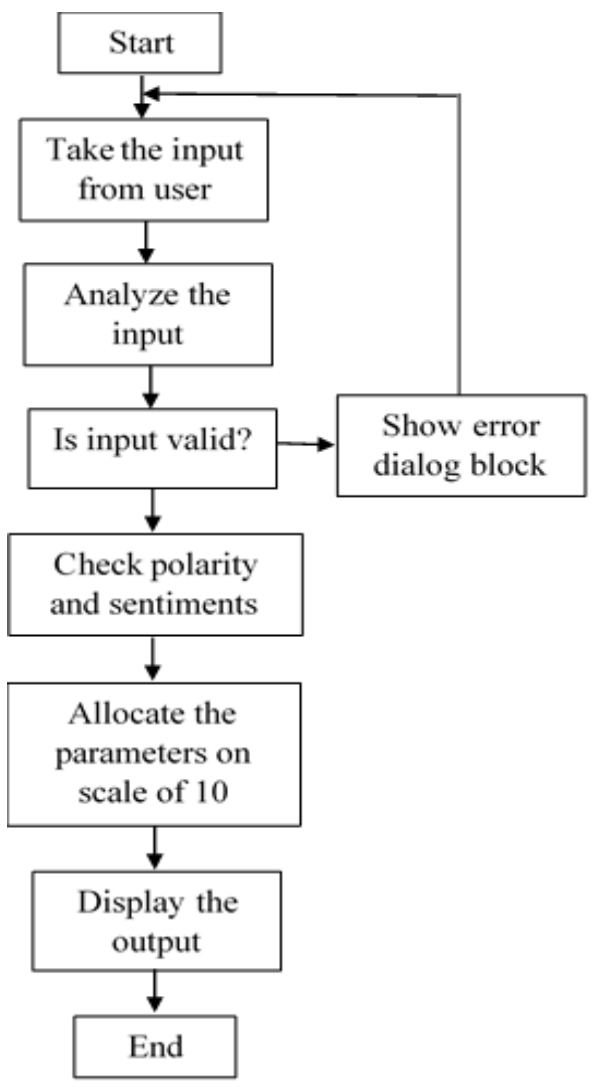

Figure 1. Flowchart SA

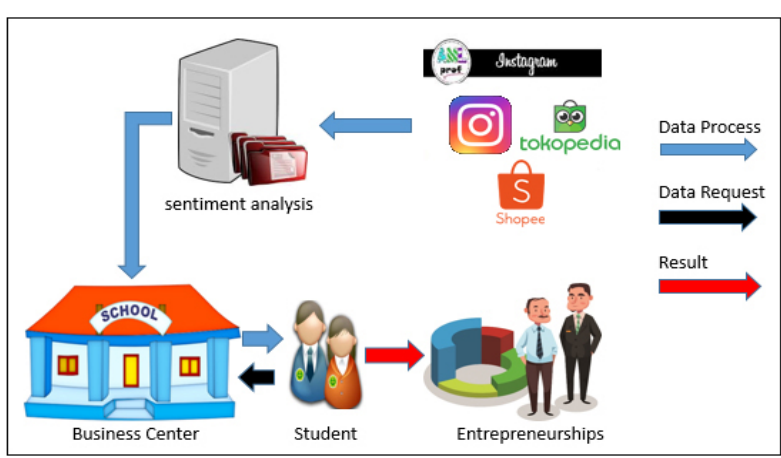

Figure 2. Design system BC using SA

Figure 2 shows how system design is built where data taken from marketplace will be processed using analytical sentiments before the data are sent to a BC in the VHS. The data can be requested by students and can be used as a learning material for students in VHS by utilizing the $\mathrm{BC}$ to be able to prepare sales strategies in the production of products that many people have an interest. This can be used as a learning to produce students who have entrepreneurial spirit and become successful entrepreneurs in accordance with the field and skills they have. The information from the data can also be used for students to enhance a new product with the modified previous product. The new products that have been produced by the students can be sold using marketplace-based BCSA to be marketable to the public. 


\subsection{Sampling and Instrument}

The number of participants in this study was 114 , consisting of 96 students of class XI, 6 administrators, and 12 teachers. Participants were selected using a purposive sampling technique in VHS management and business subjects. The technique used to collect data is a survey at SMK 7 Yogyakarta, Indonesia.

The research instruments included observation sheets and questionnaire sheets, which were given to participants after BCSA implementation. The observation sheet consisted of 12 statements that were used to identify students' entrepreneurial spirit activities during the implementation of BCSA in the marketplace database. The observation sheet has a validity value (r) of 0.883 using the product-moment correlation test and its reliability value $(\alpha)$ of 0.899 using the Croncbach alpha test. Meanwhile, the questionnaire sheet consisted of 35 statements that were used to identify the role of BCSA in the marketplace database of entrepreneurial spirit according to students, teachers, and administrator. This questionnaire sheet has also been declared valid and reliable. The validity value (r) is 0.923 using the product-moment correlation test and the reliability value $(\alpha)$ is 0.981 using the Croncbach alpha test. Thus, the instruments used have good validity and reliability, so the instruments in this study have good stability, consistency, and equivalence values [25].

Table 1. Indicator and descriptor of entrepreneurial spirit

\begin{tabular}{|c|c|}
\hline Indicator & Descriptor \\
\hline Self-confidence & $\begin{array}{c}\text { Always be calm in every occasion } \\
\text { Have sufficient potential and ability } \\
\text { Able to adapt to various situations } \\
\text { Have confidence, independence, and } \\
\text { commitment }\end{array}$ \\
\hline Originality & $\begin{array}{c}\text { The ability to create creative and innovative } \\
\text { ideas }\end{array}$ \\
& $\begin{array}{c}\text { Able to overcome new problems } \\
\text { Able to do many things well and have } \\
\text { knowledge } \\
\text { Great curiosity }\end{array}$ \\
\hline Work-oriented & $\begin{array}{c}\text { Have } \begin{array}{c}\text { a will for achievement } \\
\text { Profit-oriented }\end{array} \\
\text { Perseverance, determination, and hard work } \\
\text { Have strong drive, energy, and initiative }\end{array}$ \\
\hline Risk-taking & $\begin{array}{c}\text { The ability to take risks } \\
\text { Ready to face challenges and competition }\end{array}$ \\
\hline Good communication skills \\
Leadership & $\begin{array}{c}\text { The ability to get along well and responsibly } \\
\text { Trusted and tough in acting } \\
\text { Accept and respond to suggestions and } \\
\text { criticisms }\end{array}$ \\
\hline Future-oriented & $\begin{array}{c}\text { Visionary } \\
\text { Sharpness in perception }\end{array}$ \\
\hline
\end{tabular}

The research instrument is based on entrepreneurial spirit indicators (See Table 1) consisting of self-confidence, originality, work orientation, risk-taking, leadership, and future orientation [4],[24]. Through this instrument filling, the sentiment was obtained from the participants regarding the entrepreneurial spirit after the implementation of BCSA.

\subsection{Data Analysis Techniques}

In this study, the data analysis technique used was inferential statistics and descriptive statistics. Inferential statistics were done using the t-test analysis, while descriptive statistics were done by determining the mean, minimum and maximum scores, and entrepreneurial spirit mode.

Before data analysis is performed, the data were tested for normality and homogeneity [25]. Normality test is carried out to obtain the normal entrepreneurial spirit data distribution. The results of the normality test data using the Kolmogrov test statistic were 0.233 and the results of the normality test using the Shapiro-Wilk test were 0.753 . The significance value is more than 0.05 , so the data were stated as normally distributed [26]. Homogeneity test of sample variance between groups (student, teacher, and administrator) was used to obtain empirical data that the differences that occur in the hypothesis test actually occur due to differences in groups. Homogeneity test results for sample variance between groups using the test of equality of error variance were obtained at 2,767. The significance value was more than 0.05 , so the variance of sample data between groups was declared homogeneous [26].

\section{Results and Discussion}

\subsection{BCSA Implementation on Entrepreneurial SPIRIT}

The implementation of BSCA began with collecting product data from marketplaces, which include Instagram, Shopee, and Tokopedia. Then, SA captured the information of the product data of the public interest. The data had been obtained as a reference and input for the BC in VHS for the study of materials of students to build entrepreneurial spirit, while providing product information that represented public interest in the marketplace database. Through the implementation of BCSA, students knew the resulting product was worth selling and acceptable in the community according to the times and many people's interests. It helped the students to gain competency in building entrepreneurship. The implementation of BCSA enabled students to review and make the $\mathrm{BC}$ as a medium to foster the entrepreneurial spirit in order to create a successful entrepreneur (See Figure 3). 


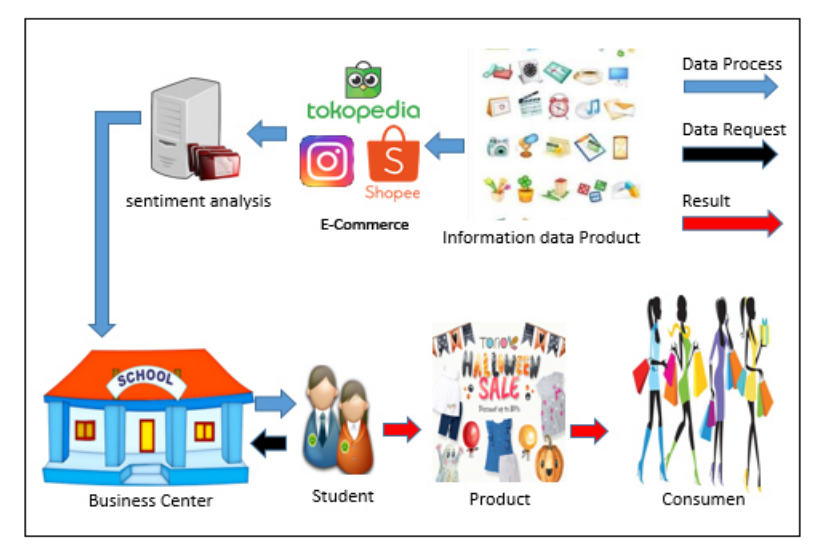

Figure 3. BCSA implementation

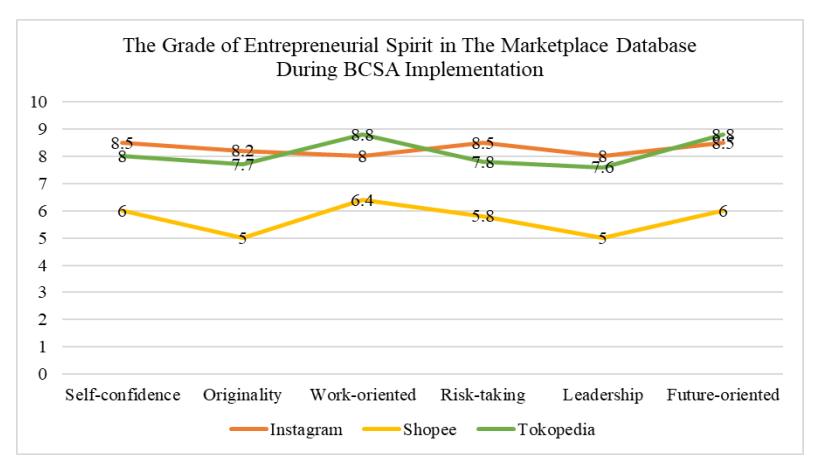

Figure 4. The grade of entrepreneurial spirit in the marketplace database during BCSA implementation

Figure 4 shows the mean value of student entrepreneurial spirit on each indicator during BCSA implementation in the marketplace database using descriptive statistics. Student entrepreneurial spirit scores have a higher mean for Instagram and Tokopedia databases than Shopee. On the other hand, the grade of entrepreneurial spirit in terms of self-confidence, originality, risk-taking, and leadership in the Instagram database was higher than Shopee and Tokopedia. The remaining grade of entrepreneurial spirit in terms of work-oriented and future-oriented was higher in the Tokopedia database than Instagram and Shopee. The interesting thing was the consistency of students' entrepreneurial spirit values in terms of confidence, work-oriented, and future-oriented in all types of marketplace databases. Thus, the entrepreneurial spirit of students through the implementation of BCSA varied depending on the type of marketplace database. In addition, through the implementation of BCSA, students have the capital of entrepreneurial spirit in terms of self-confidence, work-oriented results, and future-oriented being more consistent.

\subsection{The Role of BCSA Implementation on Entrepreneurial Spirit}

After ascertaining that the implementation of BCSA affects the fostering in entrepreneurial spirit, the role of applying BCSA to entrepreneurial spirit was analyzed using descriptive and inferential statistics based on the perspectives of students, teachers, and administrators.

Table 2. Comparison of stakeholders questionnaire results about BCSA to entrepreneurial spirit

\begin{tabular}{|c|c|c|c|c|c|}
\hline Participant & $\mathrm{N}$ & $\begin{array}{c}\text { Mean } \\
\text { Score } \\
(\%)\end{array}$ & $\begin{array}{c}\text { Min. } \\
\text { Score }\end{array}$ & $\begin{array}{c}\text { Max. } \\
\text { Score }\end{array}$ & Modus \\
\hline Students & 96 & 77.46 & 70.00 & 92.50 & 75.00 \\
\hline Teachers & 12 & 75.38 & 57.50 & 87.50 & 67.50 \\
\hline Administrator & 6 & 74.22 & 60.00 & 85.00 & 70.00 \\
\hline \multicolumn{2}{|c|}{$\mathrm{T}$} & 0.767 & df & 1.54 \\
\hline \multicolumn{2}{|c|}{ Sig. (2 tailed) } & 0.01 & $\begin{array}{c}\text { Mean } \\
\text { dif. }\end{array}$ & 3.24 \\
\hline $\begin{array}{c}\text { 95\% confidence interval of the } \\
\text { different }\end{array}$ & $\begin{array}{c}\text { Low: } 60 \\
\text { Up: } 92.50\end{array}$ & \\
\hline
\end{tabular}

Table 2 shows the role of BCSA on entrepreneurial spirit based on the perspectives of students, teachers and administrators. According to students' perspectives, the implementation of BCSA plays a role of $77.46 \%$ of entrepreneurial spirit with a response score range of 70.00-92.50. According to the teacher's perspective, the role of applying BCSA is $75.38 \%$ of entrepreneurial spirit with a response score range of 57.50-87.50. Meanwhile, according to the administrator perspective, the implementation of BCSA plays a role of $74.22 \%$ of entrepreneurial spirit with a response score range of 60.00-85.00. Thus, the results of the implementation of BCSA by using descriptive statistics have a greater role in a row against the entrepreneurial spirit, namely for students, teachers, and administrators. If converted to a rating scale, the mean score and range of response scores are in the positive category [27]. These values indicate that the implementation of BCSA provides a positive role for the formation of entrepreneurial spirit. Meanwhile, the observed value of $t$ or $t$ arithmetic was 0.767 . At the level of $0.05(\mathrm{df}=1.54)$ and the value of t-table is 1.68 [27]. The results of the statistical calculation of the inferential t-value give the conclusion that the implementation of BCSA provides a significant role for the formation of entrepreneurial spirit according to all school stakeholders.

\subsection{Discussion}

This study provides the results of identifying the role of BCSA implementation on students' entrepreneurial spirit at VHS. The main finding is the implementation of BCSA plays a role in fostering the entrepreneurial spirit of VHS students. The foster in entrepreneurial spirit mainly occurs in aspects of self-confidence, work-oriented, and future-oriented. This finding is similar to previous research that through learning activities in BCs, students will have entrepreneurship intention, so that it results in higher self-confidence in building a business [28]. The involvement of SA enabled student to read business 
opportunities [12]. Someone who has the ability to read business opportunities tends to always try to complete business targets [29]. In addition, it was found that the implementation of BCSA on the marketplace database showed a higher entrepreneurial spirit on Instagram and Tokopedia than Shopee. The reason for this was that VHS students were more interested in finding a marketplace that was also social media-oriented and did not implement a profit-sharing system [30],[28],[10].

Another important finding in this study was that the implementation of BCSA provided a positive and significant role in succession to the improvement of entrepreneurial spirit for students, teachers, and administrators. For VHS students, the BC acted as a practice facility for training entrepreneurial activities. This activity leads directly to the growth of entrepreneurial spirit, so students have good arguments for management, have an attitude of confidence, originality, orientation to work results, risk-taking, leadership, and future orientation [4]. Analysis sentiment acts as a strengthened entrepreneurial spirit in analyzing the sources and types of products that are of public interest. This makes vocational students more inspired to build their own businesses after graduation [31]. For VHS teachers, the $\mathrm{BC}$ acted as a representative simulation place to teach entrepreneurship material. In the previous research, it was shown that entrepreneurial learning using BCs makes teachers have a more effective role and time in teaching [32], [7].

The effectiveness of the role by the teacher in terms of equipping students' abilities in conducting SA occurs when students have been taught how to analyze people's buying interest and business opportunities for a particular product [31]. For VHS administrators, BC acts as an evaluation material to analyze market sentiment in order to create renewable buying and selling channels, developing new markets and developing renewable technology-based products that lead to school profits [31], [9]. From these explanations, it can be said that the role of BCSA on entrepreneurial spirit in the VHS environment depends on the magnitude of the usefulness value obtained. Consequently, the benefits of applying BCSA were greatest felt by students, teachers, and administrators. Thus, the implementation of BCSA to entrepreneurial spirit has a positive role that can be felt by all school stakeholders, especially for VHS students and teachers.

\section{Conclusions}

Based on the results and discussion of the study, the researchers concluded that the implementation of BCSA plays a role in fostering the entrepreneurial spirit of VHS students, especially in the aspects of self-confidence, work orientation, and future orientation. Besides, the implementation of BCSA provided a positive and significant role in improving entrepreneurial spirit for stakeholders in the VHS environment. The implementation of BCSA has the greatest impact on succession by students, teachers, and administrator. BCSA is recommended for use at the VHS level and subsequent studies so that VHS students have better knowledge and entrepreneurial spirit in order to prepare graduates or workforce who are better prepared for independent entrepreneurship in the future.

\section{Acknowledgments}

This research is supported by the Ministry of Finance and Research and Technology (LPDP \& DIKTI) through BUDI DN scholarship program.

\section{REFERENCES}

[1] H. Torunoğlu and D. Gençtanırım, "The Perceptions of School Counselors about the Counseling and Guidance Programs of Vocational High Schools," Procedia - Soc. Behav. Sci., vol. 174, pp. 368-376, 2015.

[2] I. Zilic, "General versus vocational education: Lessons from a quasi-experiment in Croatia," Econ. Educ. Rev., vol. 62, pp. $1-11,2018$.

[3] A. Ana, Y. Rostika, A. Juwaedah, A. Setiadi, and I. Hardikusumah, "The Effect of Personal Traits on Entrepreneurship Intention of Students at Tourism Vocational High Schools in Bandung," Online J. forTechnical Vocat. Educ. Train. ASIA, vol. 8, pp. 1-11, 2017.

[4] C. Gebhardt and M. C. Pohlmann, "Managing the organisation 2.0: Entrepreneurial spirit and general management competences as early indicators for cluster success and sustainable regional development: Findings from the German Entrepreneurial Regions Programme," $J$. High Technol. Manag. Res., vol. 24, no. 2, pp. 153-160, 2013.

[5] I. Ajzen, "The Theory of Planned Behavior," in Organizational Behavior and Human Decision Processes, 1991, pp. 179-211.

[6] N. Krueger and A. Carsrud, "Entrepreneurial Intentions: Applying the Theory of Planned Behavior," Entrep. Reg. Dev., vol. 5, no. 4, pp. 315-330, 1993.

[7] M. Weijs-Perrée, R. Appel-Meulenbroek, B. De Vries, and G. Romme, "Differences between business center concepts in The Netherlands," Prop. Manag., vol. 34, no. 2, pp. 100$119,2016$.

[8] J. Lin, Z. Luo, and X. Luo, "Understanding the roles of institutional pressures and organizational innovativeness in contextualized transformation toward e-business: Evidence from agricultural firms," Int. J. Inf. Manage., vol. 51, no. October, pp. 0-1, 2020.

[9] R. Krovi and B. S. Vijayaraman, "E-commerce content in business school curriculum: Opportunities and challenges," 
Internet High. Educ., vol. 3, no. 3, pp. 153-160, 2000.

[10] A. S. Nisafani, A. Wibisono, and M. H. T. Revaldo, "Analyzing the Effectiveness of Public e-Marketplaces for Selling Apparel Products in Indonesia," Procedia Comput. Sci., vol. 124, pp. 274-279, 2017.

[11] A. Ceron, L. Curini, and S. M. Iacus, "Using Sentiment Analysis to Monitor Electoral Campaigns: Method Matters-Evidence From the United States and Italy," Soc. Sci. Comput. Rev., vol. 33, no. 1, pp. 3-20, 2015.

[12] Y. Liu, X. Huang, A. An, and X. Yu, “ARSA: a sentiment-aware model for predicting sales performance using blogs," in Proceedings of the 30th annual international ACM SIGIR conference on Research and development in information retrieval, 2007, pp. 607-614.

[13] E. Cambria, M. Grassi, A. Hussain, and C. Havasi, "Sentic Computing for social media marketing," Multimed. Tools Appl., vol. 59, no. July 2012, pp. 557-577, 2012.

[14] B. Askun and N. Yildirim, "Insights on entrepreneurship education in public universities, in Turkey: Creating entrepreneurs or not?," Procedia-Social Behav. Sci., vol. 24, pp. 663-676, 2011.

[15] S. Faraday, C. Overton, and S. Cooper, Effective Teaching and Learning in Vocational Education. London: LSN, 2011.

[16] L. M. Lekhanya, "Critical analysis of entrepreneurial spirit, attitudes and perceptions of young South Africans in KwaZulu-Natal province," Probl. Perspect. Manag., vol. 14, no. 3, pp. 179-184, 2016.

[17] B. Liu, "Sentiment analysis and opinion mining," Synth. Lect. Hum. Lang. Technol., vol. 5, no. 1, pp. 1-167, 2012.

[18] S. Al-Natour and O. Turetken, "A comparative assessment of sentiment analysis and star ratings for consumer reviews," Int. J. Inf. Manage., vol. 54, no. August 2019, p. 102132, 2020 .

[19] J. Serrano-Guerrero, J. A. Olivas, F. P. Romero, and E. Herrera-Viedma, "Sentiment analysis: A review and comparative analysis of web services," Inf. Sci. (Ny)., vol. 311, pp. 18-38, 2015.

[20] D. J. Simon, "Sistematizando experiencias sobre educacion en emprendimiento en escuelas de nivel Primaria," Rev. Mex. Investig. Educ., vol. 18, no. 56, pp. 159-190, 2013.

[21] R. Thurik and S. Wennekers, "Points of view entrepreneurship, small business and economic growth," $J$. Small Bus. Enterp. Dev., vol. 11, pp. 140-149, 2004.

[22] P. Scourfield, "Social Care and the Modern Citizen: Client, Consumer, Service User, Manager and Entrepreneur," Br. J. Soc. Work, vol. 37, no. 1, pp. 107-122, 2005.

[23] G. Durden and V. Thyil, Charting the aspirations and urges of entrepreneurs: An asset-based prespective on entrepreneurship. 2006.

[24] R. E. Meredith, Geoffrey G. Nelson, The Practice of Entrepreneurship: 4th edition. International Labour Office, 1982.

[25] J. W. Creswell and T. C. Guetterman, Educational Research: planning, conducting, and evaluating quantitative and qualitative research, 6th Edition. Boston, United States of America: Pearson Education, 2018.

[26] J. L. Gastwirth, Y. R. Gel, and W. Miao, "The Impact of Levene's Test of Equality of Variances on Statistical Theory and Practice," Stat. Sci., vol. 24, no. 3, pp. 343-360, 2010.

[27] S. Arikunto, Prosedur Penelitian. Jakarta: Rineka Cipta, 2012.

[28] S. Top, N. Çolakoğlu, and S. Dilek, "Evaluating Entrepreneurship Intentions of Vocational High School Pupils Based On Self- Efficacy Concept," Procedia - Soc. Behav. Sci., vol. 58, pp. 934-943, 2012.

[29] C. Verzat and R. Bachelet, "Developing an Entrepreneurial Spirit Among Engineering College Students: What are the Educational Factors?," in International Entrepreneurship Education, Edward Elgar Publishing, 2006.

[30] S. Chatterjee and A. Kumar Kar, "Why do small and medium enterprises use social media marketing and what is the impact: Empirical insights from India," Int. J. Inf. Manage., vol. 53, no. March, p. 102103, 2020.

[31] J. Cui, J. Sun, and R. Bell, "The impact of entrepreneurship education on the entrepreneurial mindset of college students in China: The mediating role of inspiration and the role of educational attributes," Int. J. Manag. Educ., no. April, p. 100296, 2019.

[32] F. Rimadani and I. Murniawaty, "Pengaruh pendidikan kewirausahaan, business center, dan kreativitas siswa terhadap jiwa berwirausaha siswa," Econ. Educ. Anal. J., vol. 7, no. 3, pp. 976-991, Jan. 2019. 